\title{
Originea formelor verbale „nonfinite” cu flexiune: infinitiv vs supin
}

\author{
Adina Dragomirescu ${ }^{1,2 *}$, Alexandru Nicolae $e^{1,2 *}$ \\ ${ }^{1}$ Institutul de Lingvistică „Iorgu Iordan - Al. Rosetti,', Calea 13 Septembrie 13, 050711 București, România \\ ${ }^{2}$ Facultatea de Litere, Universitatea din București, Str. Edgar Quinet 5-7, 010017 București, România
}

\section{Despre articol}

Istoric:

Primit 1 iunie 2016

Acceptat 11 iunie 2016

Publicat 1 august 2016

Cuvinte-cheie:

infinitiv cu flexiune

supin

schimbare diacronică

extinderea structurii sintactice

\begin{abstract}
Rezumat
În acest articol ne ocupăm de două forme verbale care, deși considerate tradițional ca fiind „nonfinite”, prezintă flexiune/acord. Vom avea în vedere comportamentul și originea infinitivului cu flexiune din limbile romanice și din alte familii de limbi, pe care îl comparăm cu noul supin cu flexiune din limba română vorbită în nord-estul teritoriului românesc (Republica Moldova, Ucraina și nord-estul Moldovei). Scopul acestei cercetări este acela de a identifica traseele comune de evoluție a acestor forme verbale și de a propune o analiză formală pentru această transformare diacronică. Din perspectivă diacronică, analiza noastră arată că structura formelor nonfinite se poate extinde, o concluzie diferită de abordările tradiționale, care susțin în general că structura funcțională se simplifică diacronic. Traseul pe care îl propunem oferă sugestii și pentru analiza modificării statutului sintactic al mărcii de supin de în diacronie.
\end{abstract}

\section{Introducere}

În acest articol vom prezenta cele mai semnificative date lingvistice legate de infinitivul cu flexiune din limbile romanice și din limbi din afara familiei romanice, concentrîndu-ne asupra originii și a evoluţiei acestor forme, aşa cum reies acestea din bibliografie. După aceea, ne vom îndrepta atenția asupra unor utilizări speciale, recente, ale supinului în graiul moldovenesc din Republica Moldova, Ucraina și nordestul României ${ }^{1}$. Aceste utilizări apropie supinul românesc de infinitivul cu flexiune din alte varietăți romanice. În fine, vom propune un scenariu care să explice atît inovațiile din morfosintaxa supinului românesc (extinderea structurii sale funcționale), cît și recategorizarea diacronică a mărcii de supin de.

Pornind de la datele pe care le vom prezenta, întrebările la care ne propunem să răspundem sînt următoarele:

(i) în ce măsură este justificată includerea acestor forme verbale în categoria 'nonfinit'?;

(ii) care este relevanța originii și a evoluției acestor forme pentru comportamentul lor morfosintactic?;

(iii) prin ce se definește infinitivul (și formele nonfinite în general): prin proprietăţile legate de control, prin capacitatea de a avea subiect sau prin morfologie?;

(iv) schimbările diacronice care afectează aceste forme conduc și la procese de gramaticalizare (în sens strict)?

Am ales să comparăm supinul românesc cu infinitivul cu flexiune din alte limbi deoarece, dintre formele verbale nonfinite din română, numai supinul tinde să-și atașeze mărci flexionare, infinitivul rămînînd neflexibil sub aspectul flexiunii de persoană și de număr. Analiza supinului românesc este utilă pentru a avea o imagine de ansamblu asupra conceptului 'finit', un concept încă destul de puțin înțeles în teoria sintactică, și asupra evoluției diacronice a acestei categorii (vezi Ledgeway, 2007; Vincent, 1998).

\footnotetext{
*Adrese de corespondență: adina_drag@yahoo.com,nicolae_bibi@yahoo.com.

${ }^{1}$ În acest articol, vom folosi cu supin exemple extrase de pe internet, însă am identificat structuri de acest tip și în corpusul personal al Valentinei Cojocaru și în corpusul inclus în lucrarea Klaus Bochmann (Hrsg.) (2004). Gesprochenes Rumänisch in der Ukraine. Soziolinguistiche Verhältnisse and linguistische Strukturen, Leipziger Universitätsverlag, Leipzig.
} 


\section{Infinitivul cu flexiune}

Înainte de a trece la prezentarea datelor din limbi care au infinitiv cu flexiune, este necesar să facem o precizare terminologică (urmîndu-l pe Ledgeway, 1998) și să distingem între infinitivul 'personal', specific multor limbi, inclusiv românei (vezi Mensching, 2000), capabil de a avea propriul subiect lexical, în nominativ (1) și infinitivul 'cu flexiune' sau 'conjugat', specific unui număr mai limitat de limbi, care manifestă acord în persoană și în număr cu subiectul ori un alt tip de variație morfologică (2).

În acest articol, ne vom ocupa numai de infinitivul cu flexiune/conjugat, care este atestat în limbi diferite tipologic și genetic, precum: portugheza, galiciana, sarda, dialectele italienești din sudul Calabriei, napoletana veche, leoneza veche (dintre varietățile romanice) și maghiara, galeza, varietăți eschimose, evenki (limbă din familia manciuro-tungusă) și, probabil, greacă.

Miller (2003) a formulat ipoteza că apariția infinitivului cu flexiune este determinată de prezența subiectului lexical (acceptat de infinitivul cu flexiune în contexte foarte limitate - Ledgeway, 2000, 2007), care are trăsături de acord cu subiectul (trăsături phi) inerente.

(1) Înainte de a veni $v{ }^{2} a_{\text {subiect }}$, am muncit mult. (română)

(2) 'a cînta'

\begin{tabular}{|c|c|c|c|c|c|c|}
\hline & $\begin{array}{l}\text { Portugheză } \\
\text { europeană }\end{array}$ & $\begin{array}{l}\text { Portugheză } \\
\text { braziliană }\end{array}$ & Galeză & $\begin{array}{l}\text { Leoneză } \\
\text { veche }\end{array}$ & Sardă & $\begin{array}{l}\text { Napoletană } \\
\text { veche }\end{array}$ \\
\hline $1 S G$ & cantar- $\varnothing$ & cantar-Ø & cantar- $\varnothing$ & cantar-Ø & kantáre-po & cantare- $\varnothing$ \\
\hline $2 s G$ & cantar-es & & cantar-es & cantar-es & kantáre-s & cantare- $\varnothing$ \\
\hline $3 S G$ & cantar- $\emptyset$ & cantar- Ø & cantar-Ø & cantar- $\emptyset$ & kantáre-t & cantare- $\emptyset$ \\
\hline $1 \mathrm{PL}$ & cantar-mos & cantar-mos & cantar-mos & cantar-mos & kantáre-mus & cantare-mo \\
\hline $2 \mathrm{PL}$ & cantar-des & & cantar-des & cantar-des & kantáre-dzis & cantare-vo/ve \\
\hline $3 \mathrm{PL}$ & cantar-em & cantar-em & cantar-en & cantar-en & kantáre-n & $\begin{array}{l}\text { cantare-no } \\
\text { roothuis, 2015) }\end{array}$ \\
\hline
\end{tabular}

\subsection{Limbile romanice}

\subsubsection{Portugheza}

Dintre limbile romanice, infinitivul cu flexiune din portugheză (3) pare să fi beneficiat de cea mai multă atenție în bibliografie (Raposo, 1987; Madeira, 1994; Pires, 2002; Miller, 2003; Martins, 2006; Bossaglia, 2013; Carvalho, 2015 i.a.). Așa cum se observă din (3b), infinitivul cu flexiune poate avea un subiect lexical propriu (vezi și Rouveret, 1980).
(3) a. Depois de chegarem, fugimos după de sosi.INF.3PL am.fugit.1PL
'După ce au sosit ei, am fugit'

(Willis, 1971, p. 338, apud Bentley, 2014, p. 96)
b. despois de eles chegarem viram as ruínas după de ei.NOM sosi.INF.3PL au.văzut.3PL DEF ruinele 'după ce au sosit, au văzut ruinele'

$$
\text { (Willis, 1971, p. 338, apud Ledgeway, 1998, p. 7) }
$$

Groothuis (2015) arată că infinitivul cu flexiune din portugheza europeană organizează o structură bipropozițională, pe baza a două teste: verbul principal și infinitivul au subiecte lexicale distincte (4a) și pot fi modificate, concomitent, de acelaşi adverb (4b):
a. Nós lamentamos noi regretăm
terem eles recebido avea.INF.3PL ei 'Ne pare rău că au primit puțini bani'

$$
\text { (Raposo, 1987, p. 97) }
$$


b. É provavelmente dificíl os deputados aprovarem

este probabil greu DEF deputați aproba.INF.3PL

provavelmente a proposta

probabil DEF propunere

'Este probabil dificil ca deputații să aprobe probabil propunerea'

(adaptat după Raposo, 1987, p. 97)

Între portugheza veche și cea modernă există diferențe semnificative în ceea ce privește distribuția infinitivului cu flexiune. În primul rînd, în timp ce în portugheza modernă această formă verbală poate apărea numai în propoziții subordonate (Raposo, 1987, p. 86), portugheza veche îl accepta deopotrivă în propoziții principale și în subordonate (Martins, 2006, p. 342). În al doilea rînd, între cele două stadii de limbă apar diferențe în ceea ce privește infinitivul selectat de verbe cauzative și de verbe de percepție directă: în timp ce infinitivul canonic este acceptat după aceste verbe în ambele stadii de limbă (5a), infinitivul cu flexiune nu este atestat în portugheza veche în aceste contexte, dar este perfect gramatical în portugheza actuală (5b) (vezi și Sheehan, 2015, care ajunge la rezultate mai puțin categorice); aşadar, exemple de tipul celui din (5b) sînt neatestate în portugheza de dinainte de secolul al XV-lea, dar deja perfect gramaticale începînd cu secolul al XVI-lea (Martins, 2006).
a. Mandei/ Vi
os polícias prender
o ladrão
am.trimis am.văzut
DEF polițiști aresta.INF
DEF hoțul
b. Mandei/ Vi
os polícias
prenderem
o ladrão
am.trimis am.văzut $\mathrm{DEF}$ polițiști aresta.INF.3PL
DEF hoțul
'I-am făcut/i-am văzut pe polițiști arestîndu-l pe hoț'

(Martins, 2006, p. 327)

Se pare că această distribuție se corelează cu alte trăsături ale infinitivului canonic, din structuri cu control sau cu ridicare. Dacă în portugheza veche negaţia verbală nu putea preceda infinitivul în aceste structuri, ci numai verbul principal, în portugheza modernă atît infinitivul, cît și verbul principal pot găzdui negația verbală. Așadar, exemplul (6a) este posibil în ambele faze de limbă, pe cînd (6b) este posibil numai în portugheza modernă. Un comportament asemănător caracterizează și cliticele pronominale, care, cu puțin excepții, se ridică la verbul principal în portugheza veche, dar au ambele opțiuni-fie rămîn in situ, lîngă infinitiv, fie se ridică la verbul principal —în portugheza modernă. Deci (7a) este atestat în ambele stadii ale portughezei, pe cînd $(7 b)$ este posibil numai în portugheza modernă. Această stare de lucruri conduce la ideea că structura sintactică a infinitivului era redusă, combinația [selector + infinitiv] prezentînd semnele unei 'construcții restructurate' (Rizzi, 1978).
a. O medico DEF doctor
não $\mathrm{o}$
mandou beber vinho
nu CL.ACC.M.3SG
a.trimis
bea.INF vin
b. Omedico mandou-o
não beber vinho
DEF doctor a trimis=CL.ACC.M.3SG nu bea.INF vin
'Doctorul nu l-a trimis să bea vin'

(Martins, 2006, p. 328)

(7)
a. Mandou-lho
entregar
a trimis $=$ CL.DAT.M.SG $=$ CL.ACC
dea.INF
b. Mandou entregar-lho
a.trimis dea.INF $=$ CL.DAT.M. $3 \mathrm{SG}=$ CL.ACC
'L-a trimis să i-l dea'

(Martins, 2006, p. 328)

Martins (2006) arată că aceste fenomene sînt dovada unei schimbări de la o structură funcțională redusă a infinitivului la una mai extinsă. Vom reține ideea extinderii diacronice a structurii funcționale a formelor nonfinite pentru analiza supinului românesc din graiurile nord-estice. 


\subsubsection{Sarda}

Informații importante despre infinitivul cu flexiune din sardă (8) apar mai ales la Jones (1992, 1993, 2003) și Miller (2003). În sardă, infinitivul cu flexiune, lipsit de autonomie temporală, nu are nici un profil morfologic distinct, fiind omonim cu o formă finită, conjunctivul imperfect. Această omonimie morfologică se explică prin faptul că ambele forme își au originea în conjunctivul imperfect latinesc (Jones, 1993, p. 278).

(8) 'a cînta'

\begin{tabular}{l|ll} 
& Singular & Plural \\
\hline 1 & cantárepo & cantáremus \\
2 & cantares & cantáredzis \\
3 & cantaret & cantaren \\
& & (Jones, 1992, p. 298)
\end{tabular}

Diferența dintre cele două forme verbale se pare că este dată de tipul de complementizator care le introduce şi de topica subiectului. În (9a) conjunctivul imperfect apare într-o propoziţie introdusă de complementizatorul finit $k i$, iar subiectul este preverbal, pe cînd în (9b) infinitivul cu flexiune apare într-o propoziție nonfinită introdusă prin $a$, subiectul fiind postverbal (Jones, 1993, p. 279). Diferența de topică se asociază, de obicei, cu opțiuni diferite de deplasare a verbului în structura funcțională a propoziției (deplasare la flexiune sau la complementizator), ceea ce ar putea reprezenta o altă diferență între cele două forme.

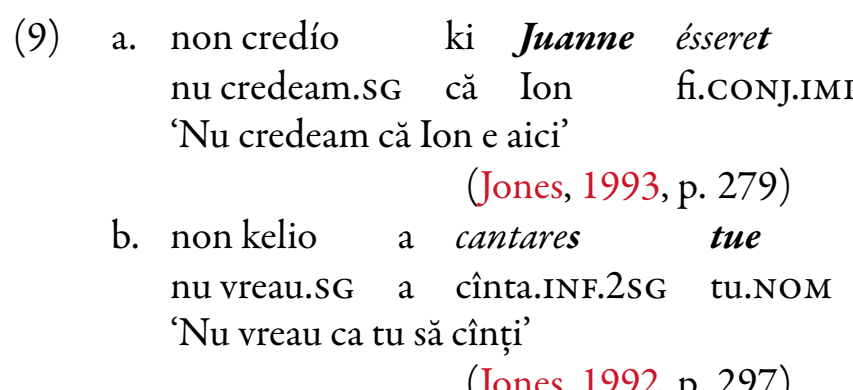

(Jones, 1992, p. 297)

În plus, distribuția celor două forme verbale nu este identică. Infinitivul cu flexiune este folosit atunci cînd subiectul acestuia are referință independentă $(10 \mathrm{a})$, dar este de regulă exclus în construcțiile cu control obligatoriu (10b).
a. devo
accabbare
custu travallu
prima
de ghiraret
trebuie.1SG termina.INF această treabă înainte de întoarce.INF.3sG
sumere
'Trebuie să termin această treabă înainte de a se întoarce șeful'
b. ?provo a travallarepo
(Jones, 1993, p. 279)
încerc a lucra.INF.1sG
'Încerc să lucrez'

(Jones, 1993, p. 280)

\subsubsection{Napoletana veche}

Infinitivul cu flexiune din napoletana veche (studiat mai ales de Ledgeway, 2007, 2009, Vincent, 1998 și Miller, 2003) apare în două tipuri de contexte (Ledgeway, 2007, p. 338-339). În contextele cu control nonobligatoriu, este și infinitiv personal, adică poate avea subiect propriu (11a-b). În contextele cu control obligatoriu, nu are subiect diferit de subiectul propoziției principale și este lipsit de autonomie temporală (11c). În ambele ipostaze, este precedat de $a$ sau de, care au fost analizate drept complementizatori. Are forme specifice numai la plural, formele de singular fiind omonime cu infinitivul canonicvezi supra, Tabelul din (2). Presiunea paradigmei de singular, care cuprindea numai forme omonime cu 
infinitivul canonic, a fost și motivul pentru care flexiunea infinitivului s-a pierdut și de la formele de plural (Ledgeway, 2007, p. 340-341).
a. ave plazuto a li nuostri Diey de nuy esseremo in questa parte a plăcut DAT DEF noștri zei de noi fi.INF.1PL în aceste părţi 'zeilor noștri le-a plăcut ca noi să fim în aceste locuri'$$
\text { (Ledgeway, 2009, p. 600) }
$$
b. per nuy averemo ordene pentru noi avea.INF.1PL ordine 'pentru ca noi să primim ordine'

$$
\text { (Ledgeway, 2009, p. 922) }
$$
c. se nui avertevamo de le andarimo appriesso
dacă noi am.considerat.PL de CL.ACC.3PL=merge.INF.1PL după
non ne scapava nissciu(n)o
nu CL.DAT.1PL=a.scăpat niciunul

'dacă am fi avut intenția să mergem după ei, niciunul nu ar fi scăpat'

(Ledgeway, 2007, p. 338)

\subsubsection{Dialecte italienești de sud}

Deși lucrările tradiționale nu recunosc existența unui infinitiv cu flexiune în varietăţile din sudul Calabriei, Ledgeway (1998) a demonstrat că propozițiile introduse prin $m u / m a / m i$ (< lat. MODO) sînt infinitivale (vezi și Miller, 2003, Ledgeway, 2007), spre deosebire de cele introduse prin $c a-/ c h i-$, care sînt finite. Argumentele pentru statutul de mărci infinitivale ale reflexelor latinescului MODo (Ledgeway, 1998, 2007; vezi și Taylor, 2016 pentru o discuție despre MODo în nicoterese) sînt:

(i) singura topică posibilă este subiect > MODO (12a), ceea ce înseamnă că MODO nu este complementizator, deoarece complementizatorii ocupă poziţii superioare ierarhic subiectului în structura propozițională;

(ii) MODO poate fi coocurent cu un alt complementizator, și anume $c a$, mai ales în propozițiile hortative (în $(12 \mathrm{~b})$, chimmu $<c a+m u)$;

(iii) propozițiile introduse prin MODO nu au referință temporală proprie, timpul subordonatei fiind anaforic, adică determinat integral de timpul propoziției principale.
a. vostra
mama mu vi vidi
Cavaleri
dumneavoastră mamă INF vă vedea.INF.3sg domni
'pentru ca mama dumneavoastră să vă vadă, domnule'
(Zungri, Fiori Selvatici, 1894, p. 125, apud Ledgeway, 1998, p. 24)
b. vi promettu, si non vi pagu, chimmu moru schjettu! vă promit dacă nu vă plăti.1sG COMP-INF muri.1sG burlac 'Vă promit, dacă nu vă plătesc, (aș vrea să) mor burlac'
(Siderno, Filocamo, 1984, p. 41, apud Ledgeway, 1998, p. 30)

Așadar, MODo din varietățile vorbite în sudul Calabriei este o marcă de infinitiv, precum $a$ și de din alte varietăți romanice, iar forma verbală pe care o introduce este similară infinitivului cu flexiune.

\subsection{Limbi nonromanice}

Există informații, destul de sumare, deci probabil incomplete, despre existența infinitivului cu flexiune și în limbi care nu aparțin familiei romanice: greaca standard și dialectul romeyka (greaca pontică, un dialect grecesc vorbit în estul Turciei), maghiara, evenki, galeza. 


\subsubsection{Greaca}

În legătură cu greaca modernă standard, Miller (2003) vorbește despre o structură cvasiinfinitivală, asemănătoare cu cea din dialectele calabreze despre care am vorbit mai sus, precedată de particula na și care prezintă acord în persoană și număr cu subiectul. Totuși, în cele mai multe lucrări, aceste structuri au fost considerate conjunctive care au înlocuit infinitivul dispărut. Argumentele lui Miller (2003) sînt următoarele:

(i) aceste structuri apar în contexte cu control obligatoriu (13);

(ii) pe baza efectelor de tip weak cross-over se poate demonstra că subiectul formelor verbale introduse de na este PRO (14);

(iii) propoziția subordonată poate fi dominată de un determinant/articol (14).
a. i Maria
prospathi-s-e na diavas- $i$
DEF Maria.NOM.SG a.încercat INF citi.3sG
'Maria a încercat să citească'
b. ? i Maria prospathise na divas-un
DEF Maria.NOM.SG a.încercat INF citi.3PL
'Maria a încercat ca ei să citească'

$$
\text { (Terzi, 1997, p. 338) }
$$
(14) pion ${ }_{\mathrm{i}}$ nevriaz-i to $\mathrm{PRO}_{\mathrm{i}}$ na plen-i to aftokinito (tu) $\mathrm{t}_{\mathrm{i}}$ cine supăra.3sG DEF INF spăla.3sG DEF mașină lui 'pe cine supără spălarea mașinii'

$$
\text { (Terzi, 1997, p. 346) }
$$

Sistemul infinitival din dialectul romeyka, studiat de Sitaridou (2014), se distinge de cel din greaca modernă standard prin două trăsături: infinitivul canonic și cel personal (capabil de a avea subiect lexical propriu) au fost conservate și a apărut o nouă formă, infinitivul cu flexiune (15).

(15) 'a spune'

\begin{tabular}{l|ll} 
& Singular & Plural \\
\hline 1 & ipina & ipiname \\
2 & ipines & ipinete \\
3 & ipine & ipinane
\end{tabular}

Sitaridou (2014) explică apariția infinitivului cu flexiune în romeyka prin apartenența acestei varietăți grecești la Sprachbund-ul caucazian.

\subsubsection{Maghiara}

Așa cum arată Miller (2003), maghiara are un infinitiv canonic, terminat în -ni, și un infinitiv cu flexiune, în structura căruia segmentul -ni este urmat de mărcile de persoană și de număr. Infinitivul cu flexiune este atestat încă din maghiara veche. În timp ce infinitivul canonic are un subiect controlat de tip PRO (16a), infinitivul cu flexiune are fie un subiect lexical, fie un subiect pronominal neexprimat, de tip pro (16b): 


\subsection{Originea infinitivului cu flexiune}

Miller (2003) a identificat două surse generale ale infinitivului cu flexiune: conjunctivul cu valoare finală (în limbile romanice și, probabil, în cele balcanice) și elemente pronominale care apar pe lîngă o nominalizare (în maghiară, varietăţi eschimose de vest, galeză). Analiza situației din diferite limbi arată că sursele sînt mai variate.

\subsubsection{Infinitivul cu flexiune provenind din alte forme verbale}

2.3.1.1. Pentru originea infinitivului cu flexiune din portugheză au fost propuse cel puțin trei ipoteze (discutate în Pires, 2002; Miller, 2003; Scida, 2004; Carvalho, 2015):

(i) José Maria Rodrigues (1913) a arătat că infinitivul cu flexiune este un descendent direct al conjunctivului imperfect din latină, atît în ceea ce privește forma (17), cît și unele funcții; acest „,onjunctiv” ar fi rămas în uz pînă în secolele al XV-lea - al XVI-lea (Ledgeway, 1998, p. 6).

$$
\begin{aligned}
& \text { lat. AMAREMUS > ptg. amar-mos } \\
& \text { iubi.INF.1PL } \\
& \text { 'a iubi' }
\end{aligned}
$$

(ii) Theodoro Henrique Maurer (1984) susține că infinitivul cu flexiune are la origine infinitivul personal (capabil de a avea subiect propriu), altfel spus, infinitivul cu flexiune s-a dezvoltat în mod analogic și spontan din infinitivul personal cu subiect în nominativ.

(iii) Gamillscheg (1970), urmat și de Miller (2003), propune o ipoteză mixtă, conform căreia infinitivul cu flexiune a rezultat din suprapunerea dintre conjuctivul imperfect din latină și infinitivul romanic în contexte specifice:
a. lat.
Placuit
(nōbis) vende-re
a.plăcut.3sG noi.DAT vinde.INF
'ne-a plăcut a vinde'
b. lat.vulg.

$\begin{array}{llll}\text { Placuit } & \text { nobis } & \text { ut } & \text { venderemus } \\ \text { a.plăcut.3sG noi.DAT } & \text { COMP } & \text { vinde.CONJ.IMPERF.1 PL } \\ \text { 'ne-a plăcut să vindem' } & & \end{array}$
c. lat.vulg. Placuit venderemus
(Roberts, 1953-1957, p. 30-31)
a.plăcut vinde.CONJ.IMPERF.1PL
'It was agreed that we sell'
d. ptg.
agradou-nos vendermos
a.plăcut-ne vinde.INF.1PL
'ne-a plăcut să vindem'

Așa cum arată Miller (2003), în latină, infinitivul (18a) și conjunctivul imperfect (18b) erau echivalente funcțional și se aflau în variație liberă în multe texte. Încă din latina timpurie, complementizatorul $u t$ 'că, să era frecvent omis, ca în (18c) (vezi Pires, 2002, p. 145). Infinitivul cu flexiune din portugheză are deci la bază structuri ca $(18 \mathrm{c})$, trecerea fiind favorizată de asemănarea formală a infinitivului canonic din latină și din portugheză (lat. vendere, ptg. vender) și de alte contexte comune de utilizare.

2.3.1.2. Infinitivul cu flexiune din napoletana veche provine din indicativul mai-mult-ca-perfect latinesc (Loporcaro, 1986; Ledgeway, 1998, p. 6; vezi însă opinia lui Martin Maiden, c.p., care respinge această ipoteză deoarece infinitivul cu flexiune păstrează tema imperfectivă din latină, și nu tema perfectivă de la care se formează mai-mult-ca-perfectul). Este interesant de remarcat că în napoletana veche toate formele nonfinite aveau variante cu flexiune, chiar dacă nu erau folosite cu aceeași frecvență pentru toate persoanele (Loporcaro, 1986, p. 173-174). 
2.3.1.3. În dialectul grecesc romeyka, infinitivul cu flexiune a apărut din infinitivul canonic, conform următorului scenariu, propus de Sitaridou (2014): în perioada medievală, este atestată o construcție formată din verbul ixa 'am avut' cu valoare contrafactivă plus infinitiv; apărînd în strictă adiacență cu verbul ixa, infinitivul și-a o creat flexiune analogică, identică cu cea de aorist a verbului ixa (20). Analogia a fost favorizată şi de identitatea formală dintre flexiunea infinitivului canonic și persoana a III-a a aoristului. Ulterior, infinitivul cu flexiune s-a extins drept complement al verbelor modale și, dat fiind că în romeyka nu există complementizatori, și în alte contexte (după verbe voliționale, cauzative și de percepție).
a. ixe ipina
a.avut spune.AOR.INF.1SG
'dacă aş fi spus'
b. ixe ipines
a.avut spune.AOR.INF.2sG
'dacă ai fi spus'

\subsubsection{Infinitivul cu flexiune provenind din alte clase de cuvinte}

2.3.2.1. În galeză, infinitivul cu flexiune este rezultatul reanalizei unor prepoziții cu flexiune (21a) ca acord al infinitivului (21b) (Miller, 2004). Galeza nu are o formă de infinitiv cu o marcare morfologică specifică, dar are substantive verbale care uneori sînt însoțite de prepoziția $i$ 'la'. Infinitivul cu flexiune a apărut, așadar, din combinația dintre marca $i$, mărcile de acord și substantivul verbal, întregul complex avînd astfel flexiune de persoană, iar prepoziția $i$ fiind reanalizată ca marcă de infinitiv (22).
a. i-daw 'la el' (galeza medie)
b. i-ddo 'la-3sG.m' (galeza modernă)
$\begin{array}{lllllll}\text { death } & \text { y } & \text { dyn } & {[i-d d y n t} & \text { ei } & \text { gweld } & \text { hi }] \\ \text { a.venit } & \text { DEF } & \text { om } & \text { la.3PL } & \text { 3sG.F } & \text { vedea.NONFIN } & \text { ea }\end{array}$
'a venit omul, pentru ca ei să o poată vedea'

(Tallerman, 1998, p. 119)

2.3.2.2. În fine, în evenki, infinitivul cu flexiune (23b) are ca sursă mărcile posesiei nominale (23a), care au devenit mărci de acord (Miller, 2003).

a. Nume + mărci de posesie (Nedjalkov, 1995, p. 443; 1997, p. 143)

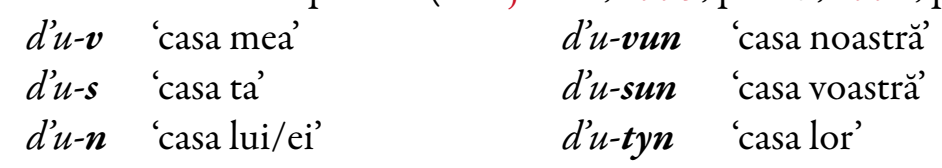

b. Infinitive cu flexiune/acord (-raki- = sufix nonfinit; baka- 'a găsi')
baka-raki-v 'a găsi eu'
baka-raki-s 'a găsi tu'
baka-raki-n 'a găsi el/ea'
baka-raki-vun 'a găsi noi'
baka-raki-sun 'a găsi voi'
baka-raki-tyn 'a găsi ei/ele'

\subsection{Rezultateși probleme}

În urma prezentării datelor legate de infinitivul cu flexiune din diferite limbi și de originea acestuia se pot formula cîteva observaţii generale:

(i) nu numai infinitivul, ci și alte forme verbale nonfinite au variante cu flexiune/acord cu subiectul în diverse limbi; în continuare, vom demonstra că și supinul românesc intră în categoria formelor „nonfinite” care au o variantă fără flexiune și una cu flexiune;

(ii) infinitivul cu flexiune din limbile romanice nu provine din infinitivul canonic, ci din forme verbale finite (conjunctiv, indicativ); încadrarea acestor forme verbale în categoria 'infinitiv' s-a făcut mai degrabă din considerente distribuţionale (sintactice) decît morfologice; 
(iii) dintre limbile analizate, se pare că infinitivul cu flexiune s-a dezvoltat din infinitivul canonic numai în romeyka și în maghiară, limbi pentru care eticheta 'infinitiv cu flexiune' pare mai potrivită; vom arăta că supinul românesc cu flexiune este o extindere a supinului canonic, ceea ce face ca româna să nu semene cu limbile romanice, ci mai degrabă cu varietăți grecești ori cu maghiara.

De asemenea, avînd în vedere datele prezentate, ne putem întreba ce este, de fapt, o formă nonfinită și ce este, de fapt, un infinitiv? Cum deosebim un infinitiv cu flexiune de un conjunctiv, în condițiile în care ambele forme pot avea flexiune și pot atribui cazul nominativ subiectului? Este adevărat că infinitivul canonic este nonfinit în sens morfologic (vezi Ledgeway, 2007, p. 336 pentru conceptul de 'finitudine morfologică), adică nu prezintă acord în persoană și număr cu subiectul, dar infinitivul cu flexiune este o formă finită din punct de vedere morfologic. Posibile răspunsuri la multe dintre aceste întrebări derivă dintr-o viziune scalară asupra conceptului 'finit' (Ledgeway, 1998, p. 8), redată prin schema din (24).

(24) a. [+ Timp, + Acord $] \rightarrow$ propoziții finite (la trecut, prezent, viitor)

b. [+ Timp, - Acord] $\rightarrow$ infinitiv personal (cu subiect propriu)

c. $[-$ Timp, + Acord $] \rightarrow$ infinitiv cu flexiune (cu subiect controlat)

d. $[-$ Timp, - Acord $] \rightarrow$ infinitiv canonic

În această schemă, (a) și (d) reprezintă opțiunile nemarcate, prezente în foarte multe limbi, iar (b) și (c) reprezintă puncte de variație interlingvistică semnificativă (vezi, pentru detalii, și Ledgeway, 2000, 2007). În secțiunea de analiză, vom identifica locul supinului românesc în această schemă.

\section{Supinul românesc: standard vs dialectal}

Se știe că supinul românesc este o formă nonfinită în sens strict, adică nu prezintă variație morfologică și, în general, nu acceptă subiect lexical, cu cîteva excepții (Pană Dindelegan, 2011; Dragomirescu, 2011). Distribuția sa este limitată la anumite contexte sintactice (Pană Dindelegan, 2008, 2013; Dragomirescu, 2013a,b). Alte trăsături relevante ale supinului verbal românesc sînt: posibilitatea de a avea obiect direct în acuzativ (25a), incompatibilitatea cu clitice pronominale (25b), cu negația propozițională (25c) și cu semiadverbe aspectuale (25d). Cliticele pronominale, negația și semiadverbele se ridică obligatoriu la verbul principal (25e).

(25) a. Termină de scris articolul.

b. ${ }^{*}$ Termină de îl scris.

c. ${ }^{*}$ Termină de $\boldsymbol{n u} / \boldsymbol{n e}$ - scris articolul.

d. ${ }^{*}$ Termină de mai scris.

e. Nû̂l mai termină de scris.

În unele varietăți vorbite în Republica Moldova, în Ucraina și în nord-estul României, supinul are însă un comportament diferit, manifestat prin:

(i) extinderea distribuției la alte contexte decît cele din româna standard;

(ii) posibilitatea de a găzdui clitice pronominale, negație verbală și semiadverbe aspectuale în anumite contexte;

(iii) posibilitatea de a se acorda cu subiectul, atunci cînd apare pe lîngă verbul a trebui sau de a primi acord după e greu de.

\subsection{Combinarea cu clitice pronominale}

Capacitatea supinului din varietățile nord-estice ale românei de a găzdui clitice a fost observată de Gabinschi (2010) și analizată de Dragomirescu \& Hill (2014) şi Dragomirescu (2015). Această disponibilitate a supinului se manifestă: 
(i) după verbe modale ca a avea (folosit personal), a trebui, a putea (folosite impersonal):

(26) a. Rusia are de ne plătit daune (historia.ro)

b. Avem de ne plătit impozitele (www.bistriteanul.ro)

c. mai aveți $d e \hat{i} \boldsymbol{i}$ adus pe mama și tata lui Liliana (ziarulnational.md)

(27) a. Trebuie de le făcut observație urgent (inprofunzime.md)

b. trebuie de le lăsat poarta deschisă spre plecare (m.publica.md)

c. Trebuie identificat persoane influente și de le convins să vină în board (www.civic.md)

a. cîte argumente se poate de le adus contra lu Ghimpu (www.publika.md)

b. se poate de le aruncat (www.publika.md)

(ii) după verbe aspectuale ca a se apuca de, a termina, a se opri:

(29) a. mă gîndesc să mă apuc de le citit (jurnalul-unei-cititoare.blogspot.com)

b. după ce termini de le arătat camerele (hd.portaltv.ro)

c. nu m-am oprit de le luat (www.naturaplant.ro)

(iii) după verbe conative ca a încerca:

(30) ca aceste răspunsuri să merite de încercat de le căutat (www.opinii.md)

(iv) după e greu de (așa-numitele 'tough-constructions'):

(31) a. eu cred că aestea mici e mai greu de le făcut (www.torrentsmd.com)

b. bune sfaturi, greu de le urmat (blogs.fanbox.com)

(v) după adjective apte de a lua complemente introduse prin prepoziția de:

(32) demne de le urmat (ro-ro.facebook.com)

(vi) în tipare de tematizare a predicației:

(33) că de le pus în geantă, tot vreau să le pun de vreo săptămînă (www.miresici.ro)

În aceste exemple se poate observa și o altă trăsătură a supinului din varietățile nord-estice, anume extinderea distribuției după verbul modal a putea (folosit impersonal) și după verbul conativ a încerca (situații neatestate în alte zone). În plus, după verbul modal a trebui se folosește numai supinul cu de, spre deosebire de limba standard, în care se folosește, în mod excepțional, supinul fără de sau participiul (vezi, pentru detalii, Sandfeld \& Olsen, 1936, p. 281; Rosetti, 1968, p. 258; Lombard, 1974, p. 301; Neamțu, 1980, p. 512-513; Pană Dindelegan, 2007, p. 170-171, 2011, p. 121; Dragomirescu, 2013a, p. 36-38, 2015).

\subsection{Combinarea cu negația verbală}

În timp ce supinul din româna standard acceptă numai combinarea cu prefixul negativ ne-, dar nu și cu negația verbală $n u$ (vezi și Cornilescu \& Cosma, 2010, pentru o interpretare diferită a negației ne-), în varietățile nord-estice supinul este compatibil cu negația verbală nu:

(34) a. Sînt multe de spus, multe de nu le spus (sorinels.blogspot.ro)

b. trebuia de nu le pus pampers (hainutebebe.com)

\subsection{Combinarea cu semiadverbe aspectuale}

Spre deosebire de limba standard, supinul din varietățile nord-estice se poate combina cu semiadverbe aspectuale:

(35) Așa că trebuie de le lăsat poarta deschisă spre plecare și de nu-i mai netezit pe bășcălie (m.publica.md) 


\subsection{Supinul acordat}

Deși în româna standard supinul nu prezintă acord în niciun context, în varietățile nord-estice, după verbul a trebui, supinul se acordă în gen și număr cu subiectul (de persoana a III-a; celelalte persoane sînt excluse din structurile cu acord), indiferent dacă acesta este ridicat în propoziția principală (36a-b) sau este postpus supinului (36c-e); acordul în gen și număr apare și în construcțiile de tipul e greu de (37).

(36) a. [situația $]_{\mathrm{F} . S \mathrm{G}}$ trebuie de analizat $\breve{\boldsymbol{a}}_{\mathrm{F} . \mathrm{SG}}$ (www.dejure.md)

b. Totuşi, [orice întrebare, temere, propunere $]_{\mathrm{F} . S \mathrm{G}}$ trebuie de discutat $\breve{\boldsymbol{a}}_{\mathrm{F} . S \mathrm{G}} \mathrm{cu}$ medicul (odoras.com)

c. că trebuie de rezolvat $\breve{\mathrm{a}}_{\mathrm{F} . \mathrm{SG}}[\text { această problemă }]_{\mathrm{F} . \mathrm{SG}}$ (protv.md)

d. trebuie de făcută $\breve{\mathrm{F}}_{\mathrm{FG}}$ [o cosmetică ușoară $]_{\mathrm{F} . S \mathrm{G}}(999 . \mathrm{md})$

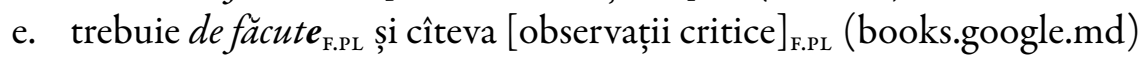

are o muncă $[\text { grea }]_{\mathrm{F} . S \mathrm{G}}$ de făcut $\breve{a}_{\mathrm{F} . \mathrm{SG}}$ (gandul.md)

\subsection{Rezultate și probleme}

Așa cum am văzut în această secțiune, supinul din varietățile nord-estice se deosebește fundamental de cel din româna standard prin: extinderea distribuției, compatibilitatea cu cliticele pronominale, compatibilitatea cu negația verbală $n u$ și cu semiadverbul aspectual mai și prin acordul în gen și număr.

În următoarea secțiune, vom încerca să încadrăm evoluția supinului românesc în contextul evoluției infinitivului cu flexiune din alte limbi și să propunem o analiză formală pentru schimbarea de comportament sintactic prin care trece în prezent supinul din varietățile nord-estice ale românei.

\section{Analiza}

În analiza noastră, adoptăm cadrul teoretic folosit în mod curent în modelul generativ actual, cu o structură a propoziției scindată în trei domenii: CP (domeniul funcțional al complementizatorului, care cuprinde complementizatorii, elementele $w h$ - și alte elemente dislocate găzduite de periferia stîngă a acestuia), IP (domeniul funcțional cuprinzînd flexiunea verbală și cliticele pronominale, responsabilă, între altele, de atribuirea nominativului) și $v \mathrm{P}$ (domeniul lexical, responsabil de generarea verbului și a argumentelor). Argumentele interne se generează și sînt marcate cazual în domeniul lexical. În schimb, argumentul extern (subiectul), deși generat în domeniul lexical (Koopman \& Sportiche, 1991), depinde de proiecția de timp generalizată (TP), care face parte din domeniul IP, pentru a fi marcat cu cazul nominativ (Chomsky, 1981; vezi Cornilescu, 2000 și Stan, 2005 pentru română).

\subsection{Supinul din româna standard}

Avînd în vedere comportamenul sintactic al supinului din româna standard (absența subiectului, incompatibilitatea cu negația verbală, cu cliticele pronominale, cu semiadverbele aspectuale), presupunem că această formă verbală, într-adevăr nonfinită, are o structură funcțională redusă—așa cum s-a propus pentru imperativul din multe limbi-, ca în (38).

Din această schemă, reiese că, în structura supinului, domeniul C nu este proiectat, iar domeniul I (care în română găzduiește proiecțiile de negație, de persoană, de mod, de timp și de aspect, ordonate astfel-vezi pentru detalii Nicolae, 2015) este deficitar: lipsește complet proiecția de Negație, cea de Timp, responsabilă de atribuirea nominativului și cea de Persoană, responsabilă pentru găzduirea cliticelor pronominale; așadar, întregul spaţiu flexionar al supinului este ocupat de marca de supin de. În schimb, domeniul lexical de sub $v$ P este complet, ceea ce se traduce prin compatibilitatea supinului cu obiectul direct (generat ca soră a verbului lexical) şi cu obiectul indirect ( $S$-a apucat de trimis cadouri copiilor), introdus ca specificator al unui grup aplicativ (ApplP) situat sub $v \mathrm{P}$ (i.e. $v>\mathrm{Appl}$ ). Absența subiectului (în structuri fără ridicare) se explică prin absența proiecției de timp: fără proiecția de timp, subiectul nu poate primi cazul nominativ, iar un nominal nemarcat cazual încalcă Filtrul de Caz (Chomsky, 1981). 
(38)

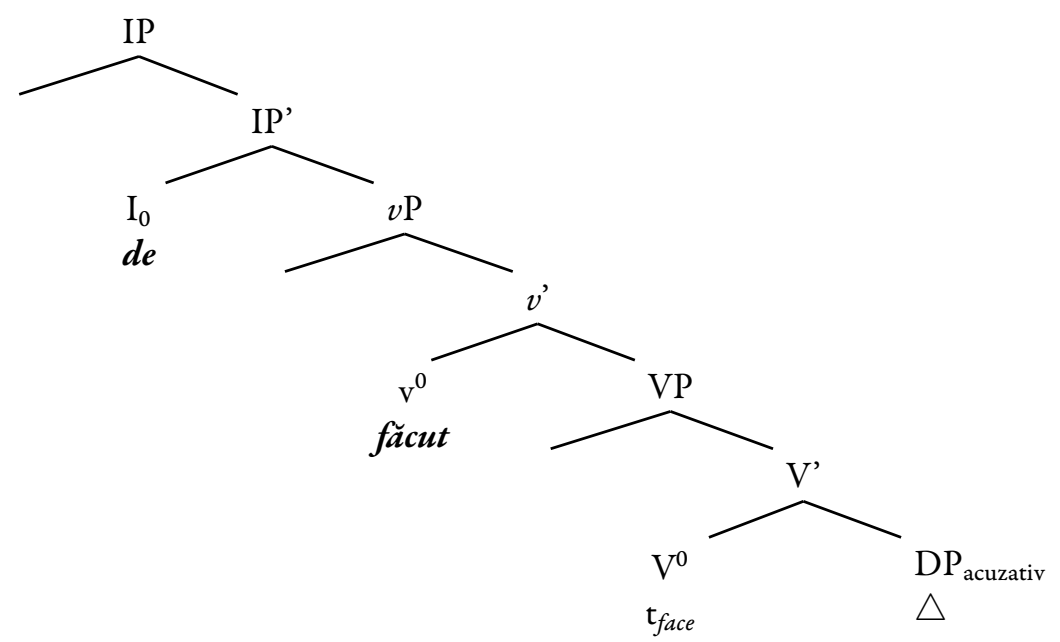

\subsection{Supinul dialectal}

Așa cum se vede din schema din (39), supinul folosit în varietățile din nord-est ale românei și-a dezvoltat o structură propozițională completă.

(39)

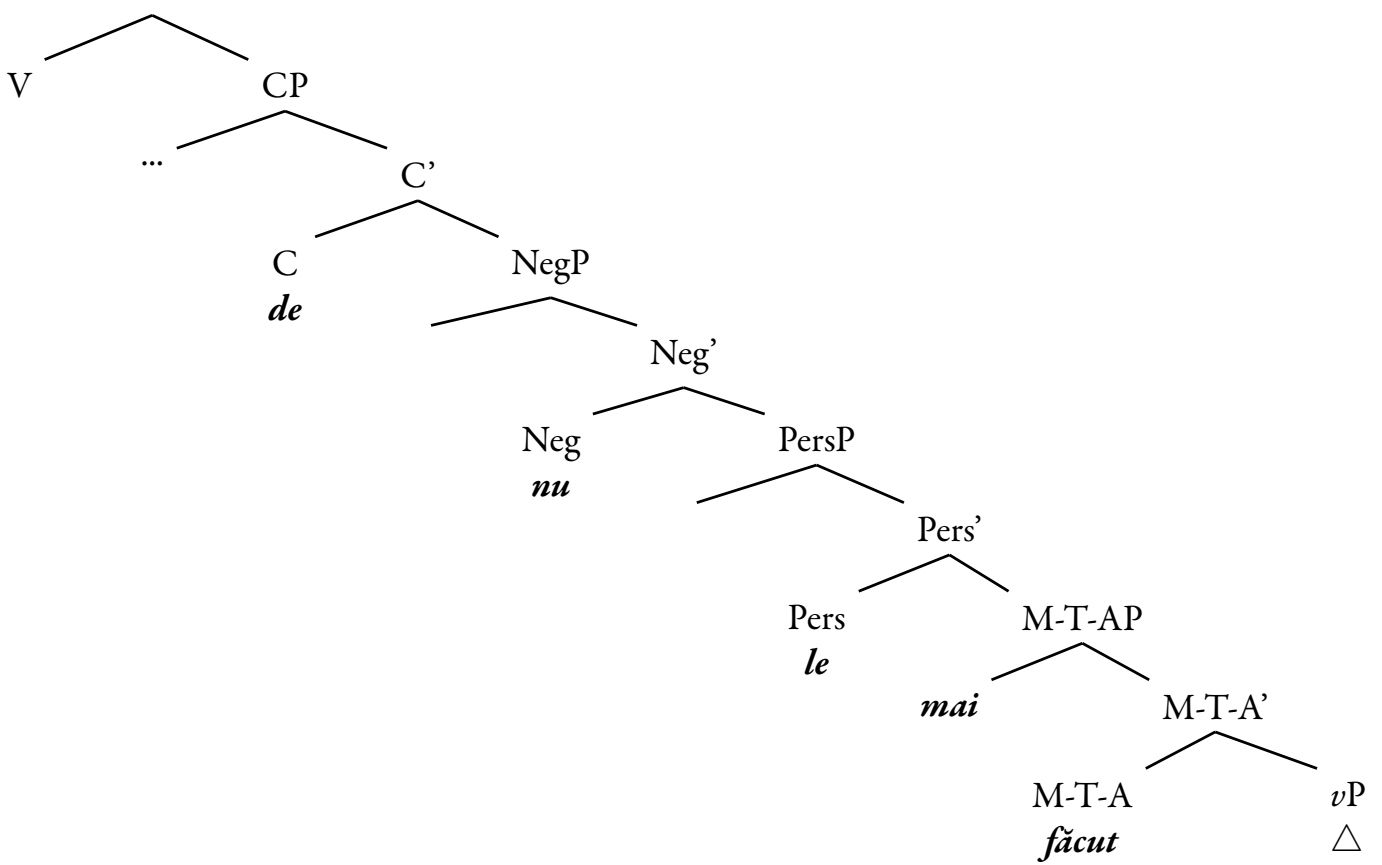

Structura funcțională a acestui supin este, așadar, similară structurii propoziției finite, în care sînt proiectate toate cele trei domenii: CP, IP și $v$ P. Domeniul C este ocupat de marca de supin de, care în aceste varietăți a fost reanalizată din marcă situată în domeniul flexionar în complementizator. În plus, se pare că domeniul CP și-a dezvoltat și o periferie care poate găzdui constituenți focalizați și topicalizați (40) (Hill \& Dragomirescu, 2014). Exemplele de mai jos sînt, în orice caz, ambigue, întrucît constituenții evidențiați prin caractere aldine pot fi interpretați ca depinzînd de predicatul principal.

(40) a. și trebuie [cumva de le adus] ca nimeni să nu știe (unimedia.info)

b. Trebuie [la bot de dat] (www.timpul.md)

Domeniul funcțional I dispune de multe dintre proiecțiile funcționale ale unei propoziții finite: proiecția de Negație, care găzduiește negația verbală, proiecția de Persoană, care găzduiește cliticele pronominale, proiecția de Aspect (/un cîmp aspectual, à la Cinque, 1999), care găzduiește semiadverbul aspectual mai. 
Din datele de pînă acum, nu există dovezi pentru existența unei proiecții de Timp: nu am identificat exemple cu supin avind un subiect propriu în nominativ, diferit de subiectul verbului principal. În concluzie, deși structura funcțională a supinului dialectal este mai bogată decît a celui din româna standard, aceasta este totuşi mai redusă sub anumite aspecte decît cea a propozițiilor finite.

Statutul propozițional al supinului dialectal este confirmat însă și de faptul că poate apărea în structuri cu topicalizare a propoziției subordonate (CP-topicalization):
a. dar [de le adus $]_{\mathrm{i}}$ trebuie $\mathrm{t}_{\mathrm{i}}$ (www.realizat.com)
b. [De le scris $]_{\mathrm{i}}$ nu e greu $\mathrm{t}_{\mathrm{i}}$, am adăugat una (forum.softpedia.com)

\subsection{Supinul pe scara finitudinii}

Încercînd să încadrăm supinul dialectal în schema din (24), propusă de Ledgeway (1998) și revizuită în lucrările ulterioare, observăm că acesta se comportă exact ca infinitivul cu flexiune din limbile romanice, avînd toate trăsăturile specifice unei propoziții finite, mai puțin capacitatea de a avea subiect lexical propriu. Așadar supinul dialectal ar avea trăsăturile [- Timp, + Acord], ceea ce înseamnă că domeniul său flexionar, deși dispune de proiecții de Negație, de Persoană, de Aspect etc. este încă incomplet, deoarece îi lipsește proiecția de Timp, responsabilă de legitimarea unui subiect propriu. Cu alte cuvinte, supinul dialectal este o formă finită din punct de vedere morfologic (adică se acordă), dar nonfinitită din punct de vedere sintactic (pentru că nu poate atribui cazul nominativ) (vezi Ledgeway, 2007).

\section{Concluzii}

În acest articol, am analizat comportamentul supinului cu flexiune din varietățile nord-estice ale românei prin comparație cu cel al infinitivului cu flexiune din diferite varietăți romanice și nonromanice.

În urma analizei, am ajuns la cîteva concluzii care privesc, pe de o parte, categoria 'finit' și manifestarea ei diacronică și, pe de altă parte, evoluția supinului românesc.

(i) Categoria 'finit' este unul dintre conceptele lingvistice cel mai puțin înțelese, care are manifestări morfologice, sintactice și semantice divergente (Ledgeway, 2007). Categoria 'finit' prezintă manifestări diacronice foarte diferite. De exemplu, în trecerea de la napoletana veche la cea modernă, infinitivul cu flexiune a fost înlocuit de infinitivul canonic, în timp ce supinul românesc, invariabil și cu o structură funcțională redusă pînă în prezent, devine, dialectal, o formă „nonfinită” cu flexiune și cu o structură funcțională îmbogățită. Așadar, diacronic, o formă verbală poată să își diminueze sau să își amplifice gradul de finitudine. În plus, este clar că 'infinitivul' din diferite limbi acoperă realităţi lingvistice destul de diferite.

(ii) Așa cum am subliniat în Secțiunea 2.4, este larg acceptată ideea că infinitivul cu flexiune din limbile romanice nu își are originea în infinitivul canonic, ci în forme verbale finite (conjunctiv, indicativ). Infinitivul cu flexiune provine din infinitivul canonic în limbi nonromanice (romeyka, maghiara). Din acest punct de vedere, româna, care are, dialectal, un supin cu structură funcțională extinsă și cu flexiune dezvoltat din supinul canonic, se aseamănă mai mult cu limbile nonromanice pe care le-am discutat.

(iii) Din perspectiva schimbărilor diacronice ale formelor nonfinite, româna se aseamănă totuși și cu limbile romanice. Dacă avem în vedere faptul că infinitivul canonic din portugheza veche nu era compatibil cu cliticele pronominale și cu negația, acestea fiind obligate să se ridice la verbul principal, iar cel din portugheza modernă poate găzdui și clitice pronominale, și negație, observăm că și procesul prin care trece supinul românesc urmează un traseu asemănător, sintetizat în (iv).

(iv) Evoluția supinului românesc presupune, în mod evident, o lărgire a structurii funcționale, proiecții (ca Negația, Persoana, Aspectul) absente din româna standard activîndu-se în varietăţile nord-estice. Fenomenul de acord al supinului în construcții cu verbul a trebui și după e greu de, încă slab atestat, dovedește că supinul tinde să își completeze inventarul de trăsături phi (morfologice). Acordul în gen face 
ca supinul românesc să difere de alte forme nonfinite cu flexiune din limbile romanice, care manifestă acord în persoană și în număr. Evoluția supinului românesc arată că îmbogățirea structurii funcționale este un tipar posibil de schimbare sintactică. Această concluzie este destul de surprinzătoare, avînd în vedere ceea ce se știe despre schimbarea sintactică: în lucrările tradiționale se insistă asupra reducerii diacronice a structurilor sintactice (vezi, de exemplu, capitolul 7 din Harris \& Campbell, 1995, Procese care simplifică structurile bipropoziționale); evoluția formelor nonfinite cu flexiune ilustrează exact situaţia opusă: îmbogăţirea structurii funcționale.

(v) Marca de supin de are un traseu istoric interesant. În momentul gramaticalizării supinului verbal din supinul ambiguu (verbo-nominal), de este reanalizat din prepoziție în marcă flexionară (Dragomirescu, 2013a,b), urmînd un tipar de gramaticalizare cunoscut, identificat, de pildă, şi pentru infinitivele cu te din neerlandeză (Ijbema, 2002). Extinderea structurii funcționale a supinului determină reanaliza mărcii de drept complementizator; cu alte cuvinte, din perspectiva structurilor din (38) și (39), de ocupă în dialectele de nord-est o poziție superioară (centru C) în comparație cu de din limba standard (centru flexionar). Această schimbare diacronică, din marcă situată în domeniul flexionar în complementizator, este în acord cu teoria schimbării sintactice propusă de Roberts \& Roussou (2003), conform cărora procesul de reanaliză / gramaticalizare presupune deplasarea / generarea / reinterpretarea elementului gramaticalizat într-o poziție superioară ierarhic.

\section{Mulțumiri}

Adresăm calde mulțumiri profesorilor/colegilor care ne-au citit articolul sau au discutat cu noi diferite probleme: Adam Ledgeway, Martin Maiden, Gabriela Pană Dindelegan, David Pesetsky. Prima versiune a acestei lucrări a fost prezentată la MIT în cadrul conferințelor LingLunch, pe 7 aprilie 2016; mulțumim colegilor de la MIT pentru comentarii și sugestii.

\section{Bibliografie}

Bentley, D. (2014). On the personal infinitive in Sicilian, în: P. Benincà, A. Ledgeway, N. Vincent (eds), Diachrony and Dialects. Grammatical Change in the Dialects of Italy, Oxford University Press, Oxford, p. 96-115, Crossref.

Bossaglia, G. (2013). Inflected/Non-inflected Infinitive Alternation in Causative and Perception Constructions of Contemporary European Portuguese: A Corpus-based study, în „Procedia - Social and Behavioral Sciences”, vol. 95, p. 220-230, Crossref.

Carvalho, M.J. (2015). Para a história do infinitive flexionado português: uma abordagen semântico-pragmática, în "Zeitschrift für romanische Philologie”, vol. 311, nr. 3, p. 664-689, Crossref.

Chomsky, N. (1981). Lectures on Government and Binding, Foris, Dordrecht.

Cinque, G. (1999). Adverbs and Functional Heads: A Cross-Linguistic Perspective, Oxford University Press, Oxford.

Cornilescu, A. (2000). The double subject construction in Romanian, în: V. Motapanyane (ed.), Comparative Studies in Romanian Syntax, Elsevier, Amsterdam / Lausanne / New York / Oxford / Shannon / Singapore / Tokyo, p. 83-133.

Cornilescu, A. \& Cosma, R. (2010). Remarks on the Romanian Verbal Supine and its German Equivalents, comunicare la The Annual Conference of the Faculty of Foreign Languages and Literatures, Universitatea din București, 5-6 noiembrie.

Dragomirescu, A. (2011). The subject of the supine clause in Romanian and A-chains, în "Revue roumaine de linguistique”, vol. LXI, nr. 4, p. 371-392.

Dragomirescu, A. (2013a). Particularități sintactice ale limbii române în context romanic. Supinul, Editura Muzeului Naţional al Literaturii Române, București.

Dragomirescu, A. (2013b). Du latin au roumain. Une nouvelle hypothèse sur l'origine du supin en roumain, în „Revue de linguistique romane", vol. 77, nr. 305-306, p. 51-85.

Dragomirescu, A. (2015). Utilizări dialectale ale supinului, în: R. Zafiu, I. Nedelcu (eds.), Variația lingvistică: probleme actuale. Actele celui de al 14-lea Colocviu al Departamentului de Lingvistică, I, Editura Universității din București, București, p. 3948.

Dragomirescu, A. \& Hill, V. (2014). A diachronic perspective on de-supine complements, comunicare la ACED, Universitatea din București, 5-7 iunie.

Gabinschi, M. (2010). Formele verbale nepredicative nonconjunctivale ale limbii române (pe marginea tratării lor în gramatica oficială), Chișinău.

Gamillscheg, E. (1970). Studien zur Vorgeschichte einer romanischen Tempuslehre (= Sitzungsberichte der Kais. Akademie der Wissenschaften in Wien, Phil.-hist. Kl., 172. Bd., 6. Abhandlung.), Tubinger Beitrage zur Linguistik, Tubingen; ed. I: 1913. 
Groothuis, K. (2015). The inflected infinitive in Romance, comunicare la workshop-ul Romance Syntax. Comparative and Diachronic Perspectives, Universitatea din București, 27-28 noiembrie.

Harris, A. \& Campbell, L. (1995). Historical Syntax in Cross-Linguistic Perspective, Cambridge University Press, Cambridge, Crossref.

Hill, V. \& Dragomirescu. A. (2014). De-supine complements in Romanian: a paradigmatic view, comunicare la LSRL 44, 2-4 mai.

Ijbema, A. (2002). Grammaticalization and infinitival complements in Dutch, LOT Publications, Utrecht, [online].

Jones, M. A. (1992). Infinitives with specified subjects in Sardinian, în: C. L Laeufer, T. A. Morgan (eds), Theoretical analyses in Romance linguistics, John Benjamins, Amsterdam, p. 295-309, Crossref.

Jones, M. A. (1993). Sardinian syntax, Routledge, London.

Jones, M. A. (2003). Sintassi della lingua sarda: Sardinian syntax (R. Bolognesi, Trans.), Condaghes, Cagliari.

Kiss, K. (1987). Configurationality in Hungarian, Reidel, Dordrecht - Boston, Crossref.

Koopman, H. \& Sportiche, D. (1991). The Position of Subjects, în „Lingua”, vol. 85, nr. 2-3, p. 211-258, Crossref.

Ledgeway, A. (1998). Variation in the Romance infinitive: the case of the Southern Calabrian inflected infinitive, in "Transactions of the Philological Society", vol. 96, nr. 1, p. 1-61, Crossref.

Ledgeway, A. (2000). A Comparative Syntax of the Dialects of Southern Italy: A Minimalist Approach, Wiley-Blackwell, Oxford.

Ledgeway, A. (2007). Diachrony and Finiteness: Subordination in the Dialects of Southern Italy, în: I. Nikolaeva (ed.), Finiteness: Theoretical and Empirical Foundations, Oxford University Press, Oxford, p. 335-365.

Ledgeway, A. (2009). Grammatica diacronica del napoletano, Niemeyer, Tübingen.

Lombard, A. (1974). La langue roumaine. Une présentation, Éditions Klincksieck, Paris.

Loporcaro, M. (1986). L'infinito coniugato nell'Italia centro-meridionale: ipotesi genetica e ricostruzione storica, în „Italia dialettale", vol. 49, p. 173-140.

Madeira, A.-M. (1994). On the Portuguese Inflected Infinitive, în „UCL Working Papers in Linguistics”, 6, p. 179-203.

Martins, A.M. (2006). Aspects of infinitival constructions in the history of Portuguese, în: R. Gess, D. Arteaga (eds), Historical Romance Linguistics: Retrospective and perspective, John Benjamins, Amsterdam, p. 327-355, Crossref.

Maurer, T.H., Jr. (1984). O Infinito Flexionado Portugues: Estudo historico-descritivo, Editora Nacional, Sao Paulo; ed. I: 1968.

Mensching, G. (2000). Infinitive Constructions with Specified Subjects. A Syntactic Analysis of the Romance Languages, Oxford University Press, Oxford.

Miller, D.G. (2003). Where do conjugated infinitives come from, în „Diachronica”, vol. 20, nr. 1, p. 45-81, Crossref.

Miller, D. G. (2004). The origin of the Welsh conjugated infinitive, în „Diachronica”, vol. 21, nr. 2, p. 329-350, Crossref.

Neamțu, G. G. (1980). Despre construcția „a trebui + participiu”, în „Limba română”, vol. XXIX, nr. 5, p. 511-514.

Nedjalkov, I.V. (1995). Converbs in Evenki, în: M. Haspelmath, E. Konig (eds), Converbs in Cross-Linguistic Perspective. Structure and meaning of adverbial verb forms-adverbial participles, gerunds, Mouton de Gruyter, Berlin - New York, p. $441-463$.

Nedjalkov, I.V. (1997). Evenki, Routledge, London - New York.

Nicolae, A. (2015). Ordinea constituenților în limba română: operspectivă diacronică. Structura propoziției și deplasarea verbului, Editura Universității din București, București.

Pană Dindelegan, G. (2007). Din nou despre participiu şi supin, în „Studii şi cercetări lingvistice”, vol. LVIII, nr. 1, p. $163-173$.

Pană Dindelegan, G. (2008). Supinul, în: V. Guțu Romalo (ed.), Gramatica limbii române, I. Cuvântul, Editura Academiei Române, București, p. 509-524.

Pană Dindelegan, G. (2011). Din istoria supinului românesc, în: R. Zafiu, C. Uşurelu, H. Bogdan Oprea (eds.), Limba română - ipostaze ale variației lingvistice, I, Editura Universității din Bucureşti, Bucureşti, p. 119-130.

Pană Dindelegan, G. (2013). The supine, în: G. Pană Dindelegan (ed.), The Grammar of Romanian, Oxford University Press, Oxford, p. 233-245.

Pires, A. (2002). Cue-Based Change: Inflection and Subjects in the History of Portuguese Infinitives, în: D. Lighfoot (ed.), Syntactic Effects on Morphological Changes, Oxford University Press, Oxford, p. 143-159, Crossref.

Raposo, E. (1987). Case Theory and Infl-to-Comp: The Inflected Infinitive in European Portuguese, în „Linguistic Inquiry”, vol. 18, nr. 1, p. 85-109.

Rizzi, L. (1978). A restructuring rule in Italian syntax, în: S. J. Keyser (ed.), Recent Transformational Studies in European Languages, MIT Press, Cambridge, MA, p. 113-158.

Roberts, I. \& Roussou, A. (2003). Syntactic Change. A Minimalist Approach to Grammaticalization, Cambridge University Press, Cambridge.

Roberts, K.S. (ed.) (1953-1957). An Anthology of Old Portuguese, Livraria Portugal, Lisbon.

Rodrigues, J. M. (1913). O imperfeito do conjuntivo e o infinitivo pessoal no Portugues, în „Academia das Sciencias de Lisboa: Boletim da Segunda Classe", 8, p. 72-93.

Rosetti, Al. (1968). Istoria limbii române de la origini pînă în secolul al XVII-lea, Editura pentru Literatură, Bucureşti.

Rouveret, A. (1980). Sur la notion de proposition finie. Gouvernement et inversion, în „Langages”, vol. 14, nr. 60, p. 75-107, [online].

Sandfeld, Kr. \& Olsen, H. (1936). Syntaxe roumaine. Emploi des mots à flexion, I, E. Droz, Paris. 
Scida, E. (2004). The inflected infinitive in Romance languages, Routledge, New York - London.

Sheehan, M. (2015). Control of Inflected Infinitive in European Portuguese, ms, [online].

Sitaridou, I. (2014). The Romeyka infinitive. Continuity, contact and change in the Hellenic varieties of Pontus, în „Diachronica”, vol. 31, nr. 1, p. 23-73, Crossref.

Stan, C. (2005). Categoria cazului, Editura Universităţii din București, București.

Tallerman, M. (1998). The Uniform Case-licensing of Subjects in Welsh, în „The Linguistic Review”, vol. 15, nr. 1, p. 69-133.

Taylor, C. (2016). Aspects of Clause Structure in Nicoterese. A Descriptive Account, teză de doctorat, University of Cambridge. Terzi, A. (1997). PRO and Null Case in Finite Clauses, în „The Linguistic Review”, vol. 14, nr. 4, p. 335-360.

Vincent, N., (1998). On the grammar of inflected non-finite forms (with special reference to Old Neapolian), în: L. Korzen, M. Herslun (eds), Clause combining and text structure, Samfundlitteretur, Copenhagen, p. 135-158.

Willis, C. (1971). An essential course in Modern Portuguese (Revised edition), Nelson, Hong Kong. 